CURRENT RESEARCH JOURNAL OF PEDAGOGICS

(ISSN -2767-3278)

VOLUME 03 ISSUE 01 Pages: 17-21

SJIF IMPACT FACTOR (2021: 5 • 714)

OCLC-1242041055 METADATA IF - 8.145

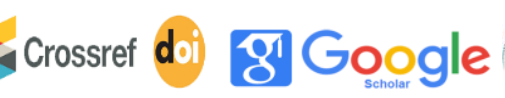

14. netnD

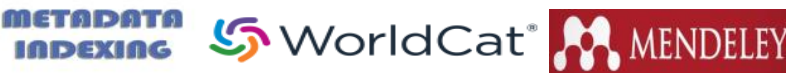

Publisher: Master Journals

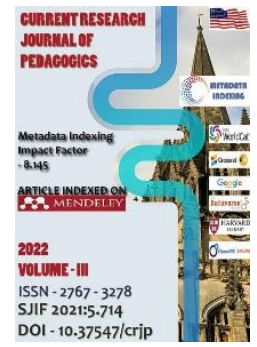

Journal Website: https://masterjournals. com/index.php/crip

Copyright: Original content from this work may be used under the terms of the creative commons attributes 4.0 licence.
Research Article

\section{PROBLEMS OF TEACHING PRESCHOOL CHILDREN IN FINE} ACTIVITIES

Submission Date: December 30, 2021, Accepted Date: January 11, 2022, Published Date: January 21, 2022

Crossref doi: https://doi.org/10.37547/pedagogics-crjp-03-01-03

Oybarchin Makhmudova

Associate Professor, Tashkent State Pedagogical University, Tashkent, Uzbekistan

\title{
ABSTRACT
}

The continuous improvement of issues in the field of education and the emergence of new opportunities require the constant updating of teaching methods for the successful implementation of the task of improving the quality and effectiveness of education in preschool education. A number of pedagogical and psychological scientific works have been carried out in the history of pedagogy to study specific aspects of children's fine arts.

\section{KEYWORDS}

Preschool children, visual activities, education, preschool education organizations, quality of education.

\section{INTRODUCTION}

The analysis of scientific, psychological and pedagogical literature on the basis of these views shows that preschool education has been given importance for centuries.
This is evidenced by historical sources on the teaching of fine arts in ancient Egypt. The fact that people have been engaged in the teaching of fine arts since ancient times has been preserved in more ancient Egyptian 
CURRENT RESEARCH JOURNAL OF PEDAGOGICS

(ISSN -2767-3278)

VOLUME 03 ISSUE 01 Pages: 17-21

SJIF IMPACT FACTOR (2021: 5. 714)

OCLC - 1242041055 METADATA IF - 8.145
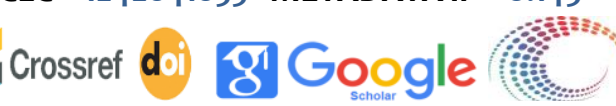

metapenta

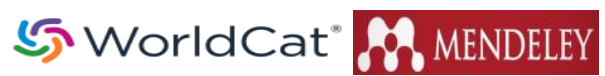

Publisher: Master Journals

sources. Historically, school leavers have been required to be able to measure the area of a particular area and draw it on paper, draw a plan of a building, and draw a diagram of canals and canals [7].

Italian art in the Renaissance and the method of teaching it played a major role. During this period, drawing was included in the list of general education subjects. Famous artists Chennino Chennini, Leon Batista Alberti, Leonardo da Vinci have done remarkable work in this regard. In their works, the issues of the relationship between science and art, proportion, perspective, anatomy took a central place. In their opinion, it is necessary to organize the basis of teaching painting, depending on the nature.

\section{THE MAIN RESULTS AND FINDINGS}

In particular, Leonardo da Vinci (Leonardo di ser Piero da Vinci, 1452-1519) had a great influence on the development of methods of teaching fine arts. In his work, Treatise on Painting, he considers painting to be a serious branch of science. Over the years, he developed the laws of anatomy, color, and proportions between human organs.

It is known that art develops only on the basis of the traditions formed over many years by several generations, the knowledge passed from master to student. This is an indication that it has developed in the form of professional art education, albeit not in the direction of unconditional general art education. This is evidenced by the fact that during the reign of Amir Temur, an independent state flourished miniature art. During the reign of Amir Temur, miniature and book graphics developed so rapidly that it had an impact not only on the art of the East, but also on the art of European countries. As a result, along with Samarkand, Bukhara, Herat miniature schools, Baghdad, Tabriz,
Sheroz, Azerbaijan, India, Isfahan, Turkish miniature schools were formed and developed [7].

A. Dürer (Albrecht Dürer, 1471-1528), one of the German artists of the Renaissance, made a great contribution to the improvement of the teaching of fine arts. He was the first to invent a geometric method to facilitate drawing. According to him, the basis of any object is a geometric body shape. Therefore, in describing this or that thing, it is necessary to first draw the shape of a geometric object, and then they are generalized and said that a real image is formed. Later, this method was widely used in the pedagogical activities of Paul Michel Dupuyi (Dupuy Paul Miche, 1869-1949), A.Ajbe (Anton Ažbe, 1862-1905), P.P. Chistyakov. Even today, this method has not lost its power. According to D.N. Kardovsky, when drawing a picture of a person, a head, or a still life, "the model should be drawn by dividing it into the most general lines possible." [9]

In general, it is a mistake to think that aesthetic education is just a simplified, art-specific teaching of a child.

The usefulness of teaching fine arts in all secondary schools is developed by the great Czech pedagogue J.A. Comenius (1592-1670) in his work "The Great Didactics" [7].

Professor Franz Chizhek (Frans Chizhek, 1865- 1946) first opened his first art class in 1897 at the Vienna School of Decorative and Applied Arts. This method of Frank Chijek is known in history as the man who taught the innovative method of teaching children the "Chijek method" and is its founder. This innovative method of the professor has been widely introduced in Europe, the United States, India, Japan, art classes based on the principle of freedom, and has not lost its success even today. Frank Chijek also coined the term "Children's 
CURRENT RESEARCH JOURNAL OF PEDAGOGICS

(ISSN -2767-3278)

VOLUME 03 ISSUE 01 Pages: 17-21

SJIF IMPACT FACTOR (2021: 5. 714)

OCLC - 1242041055 METADATA IF - 8.145
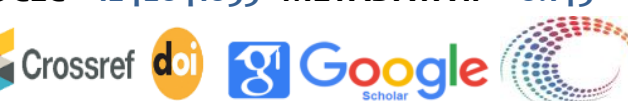

metapenta

5) WorldCat ${ }^{\circ}$ fी MENDELEY

Publisher: Master Journals

Picture" in 1890, but there was no generally accepted definition of the term.

By the end of the XIX century, children's drawings attracted the attention of foreign scientists in various fields, psychologists, educators, ethnographers, art critics. Thus, the emergence of a new direction in psychology - the science of child psychology - was associated with the development of science and culture. In the study of child psychology through the study of children's drawings, they were considered as objective material to determine their general and individual characteristics. In a series of works on child psychology abroad, a great deal of attention has been paid to the analysis of children's drawings.

Founder of Child Psychology in England, James Sully (1843-1923), a well-known English psychologist, described the basic principles of child development in his book Essays on Child Psychology (1895) describes the stage.

Italian art critic Ricci Corrado (1858-1934) was the author of The Deti Khudojniki (1887), a work devoted to the psychological analysis of children's paintings. Explains the uniqueness of children's art by exploring children's many paintings. Based on his research, Richchi concludes that the child does not draw like an artist, but conveys exactly what was created in his memory. Children with good memory draw better, and over time, drawing is not only a product of memory, but also the result of other elements such as aesthetic taste, dexterity, and improvement of visual performance. [10]

Russian psychiatrist, neuropathologist, physiologist, psychologist, founder of reflexology and pathopsychology in Russia, academician VM Bekhterev (1857-1927) and a lot of evidence based on the analysis of children's drawings that the general features of children's drawing development are the same, a scientist who studied the problem of the gradual evolution of children's drawings [8].

In the early twentieth century, the system of preschool education in the former Soviet republics became a nationwide affair.

The methodology of teaching fine arts as a pedagogical science developed as a part of pedagogical science until the 1920s, and then formed as an independent science. The first doctor of preschool education pedagogy E. A. Flerina's research was the basis for the development of the main problems of the theory and methodology of visual activity in preschool education [12]. At that time, there was no clearly developed curriculum and teaching methods in the preschool education system. An example of this area is the school of N.P. Sakulina, the strongest and most comprehensive scientific school of preschool art methods. N.P. Sakulina explains that when an adult gives a child a pencil and paper, the first pictures of the child appear, which also applies to clay work (sculpture). A child's interest in visual activities begins at an early age and continues to develop at a preschool age [11].

The study of the characteristics of children's development in the new environment, the creation of new textbooks and the training of qualified teachers was a requirement of the time.

An analysis of the problem of teaching visual arts in preschool children in pedagogical theory shows that in the first half of the twentieth century, much attention was paid to the development of methods of guiding the visual activities of early childhood. As a result of the research, the curriculum for teaching young children has become more clear and some ways to guide the 
CURRENT RESEARCH JOURNAL OF PEDAGOGICS

(ISSN -2767-3278)

VOLUME 03 ISSUE 01 Pages: 17-21

SJIF IMPACT FACTOR (2021: 5 • 714)

OCLC - 1242041055 METADATA IF - 8.145
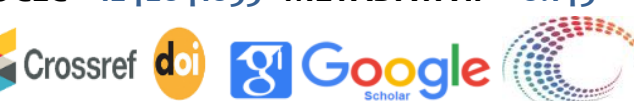

metapata

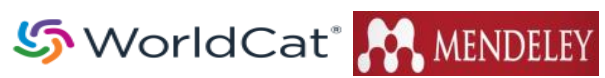

Publisher: Master Journals

visual activities of young children have been developed.

In the research work of F.Valikhodjaeva aimed at preparing students for the aesthetic education of children in preschool education, the scope of activities and their effective results in the training of young professionals in preschool education on the basis of modern requirements for aesthetic education and social pedagogical needs have been scientifically confirmed experimentally.

While acknowledging the important role of visual arts in the development of children's creative abilities, DT Sabirova's research showed that such trainings undoubtedly lay the foundation for the formation of literacy elements in them.

Constant attention is paid to the issues of educating the younger generation. In accordance with the Decrees and Resolutions of the President of the Republic of Uzbekistan on the system of preschool education, major changes have begun in the system of preschool education. Another important document in the national legislation is the Concept of Development of the Preschool Education System of the Republic of Uzbekistan until 2030. An important aspect of this document is the creation of conditions for the comprehensive intellectual, moral, aesthetic and physical development of preschool children, raising the level of artistic, aesthetic and musical education and training of preschool children, the introduction of STEAM teaching from an early age.

One of the most important indicators of children's readiness for school is their level of mental, physical, aesthetic, psychological development and normative indicators "State requirements for the development of primary and preschool children of the Republic of Uzbekistan" and the state curriculum "First Step" painting, clay work, cutting and gluing works are carried out in the development center on the basis of application) and have a number of features. This allows children to develop mental activity, creativity, artistic taste and other human qualities in children with each type of visual activity. Children who have the opportunity to develop their imagination and creativity in various forms learn to respect the national spiritual heritage and culture. The child learns to express their feelings through music, theater, visual activities.

The Concept of Preschool Education, developed for preschool education organizations, aims to create conditions for the comprehensive intellectual, moral, aesthetic and physical development of preschool children. step "From the analysis of the structure and content of the state curriculum, it is clear that most of the time, starting from a small group, is devoted to visual activities.

If we add other types of visual activities - application (0.5 hours), construction (0.5 hours) and clay work (1 hour), the total is 4 hours. Considering that the weekly loading is 12 hours, visual activity accounts for one-third of all activities [13].

\section{CONCLUSION}

Preparing children for school is a very complex process and requires special knowledge from parents. It is well known that from the moment a child regains consciousness, he becomes very fond of drawing in the right place with what he can get his hands on. Our task is to direct this aspiration and interest in children in the right direction. It is advisable to prepare children for the fine arts from an early age. This is because the earlier children engage in goal-oriented activities, the sooner they will have the necessary experiences [14]. 
CURRENT RESEARCH JOURNAL OF PEDAGOGICS

(ISSN -2767-3278)

VOLUME 03 ISSUE 01 Pages: 17-21

SJIF IMPACT FACTOR (2021: 5• 714)

OCLC - 1242041055 METADATA IF - 8.145

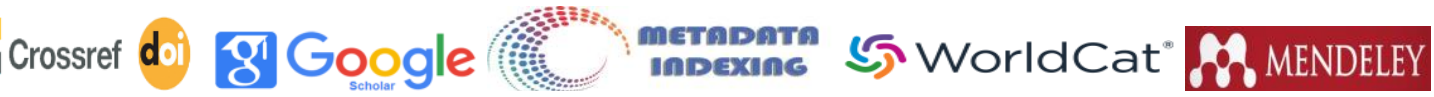

9. James Sully Essays on the psychology of childhood. [per. from English. A.Grombach] Moscow, Kuzenets.most.1903

Thus, visual activity is the largest section that acquires integrative content and is carried out in a logical and didactic connection with other types of activities. This factor means that the content and methodology of visual activities need to be improved in line with other activities.

\section{REFERENCES}

1. Law of the Republic of Uzbekistan on preschool education and upbringing. No. ORQ595. - T .: $2019 \mathrm{y}$.

2. Resolution of the President of the Republic of Uzbekistan dated December 29, 2016 No PP2707 "On measures to further improve the system of preschool education in 2017-2021."

3. Resolution of the President of the Republic of Uzbekistan No. PP-3305 "On the organization of the Ministry of Preschool Education".

4. The Concept of development of the system of preschool education of the Republic of Uzbekistan till 2030 according to the order of the President of the Republic of Uzbekistan from May 8, 2019 of No. PP-4312 May 13, 2019, No. 19 , Article 364.

5. "State requirements for the development of primary and preschool children." - T .: 2018

6. The state curriculum of the preschool educational institution "First step". - T .: 2018

7. Abdirasilov S.F. Methods of teaching fine arts. T .: «Science and technology», 2012, 232 pages.

8. Bekhterev. V.M. The initial evolution of children's drawing in an objective study / Moscow; Voronezh // Problems of human development and education: selected psychological works /; Voronezh: MODEK, 2010. - S. 167-224. 